\title{
Temperature and plant hardiness zone influence distribution of balsam woolly adelgid damage in Atlantic Canada
}

\author{
Dan Quiring ${ }^{1}$, Don Ostaff², Lester Hartling ${ }^{3}$, Dan Lavigne ${ }^{3}$, Keith Moore ${ }^{4}$ and lan DeMerchant²
}

\begin{abstract}
Management of balsam woolly adelgid (Adelges piceae Ratz.) and of trees damaged by this pest may pose one of the biggest challenges to forest management in Atlantic Canada during the next decade. Feeding by the balsam woolly adelgid is restricted to Abies species in which it causes gouting, branch and upper crown death. Approximately 100 years after its introduction into eastern Canada, symptoms of feeding by the balsam woolly adelgid on balsam fir are found throughout all of Nova Scotia, most of Newfoundland and in southern and eastern New Brunswick. The distribution of symptomatic balsam fir trees coincides with areas where mean January temperatures are below $-11^{\circ} \mathrm{C}$ and where plant hardiness zones are higher than 4a. The presence of balsam fir trees with obvious symptoms of BWA damage throughout much of Atlantic Canada emphasizes the ubiquitous presence of this pest in these provinces and highlights the need to develop hazard rating systems to establish pest management programs to diminish its impact.
\end{abstract}

Key words: global warming, Adelges piceae Ratz., forest insect pest management, abiotic factors

\section{RÉSUMÉ}

Le contrôle du puceron lanigère du sapin (Adelges piceae Ratz.) et des arbres endommagés par ce ravageur pourrait constituer l'un des plus importants défis de l’aménagement forestier dans la Région de l'Atlantique au Canada au cours de la prochaine décennie. Lalimentation du puceron lanigère se limite au genre Abies et provoque des écoulements et la mort des branches et de la partie supérieure de la cime. Près de 100 ans après son introduction dans lest du Canada, les traces d’alimentation laissées par le puceron lanigère du sapin sur cet arbre se retrouvent partout en Nouvelle-Écosse, sur la majeure partie de Terre-Neuve et dans le sud et l'est du Nouveau-Brunswick. La distribution des sapins baumiers affectés

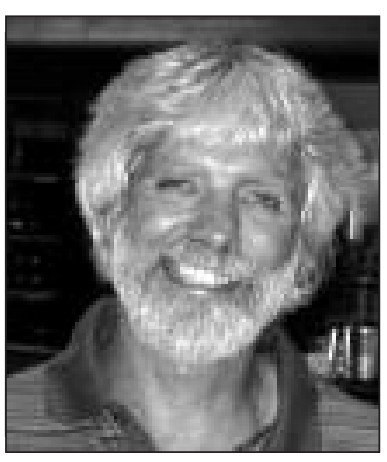

Dan Quiring

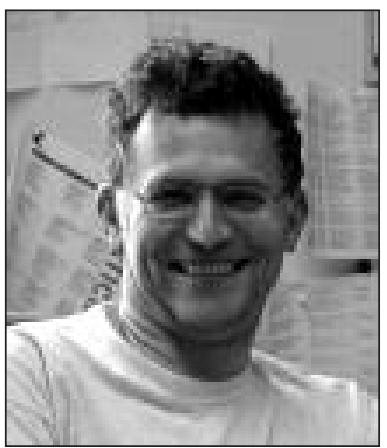

Lester Hartling

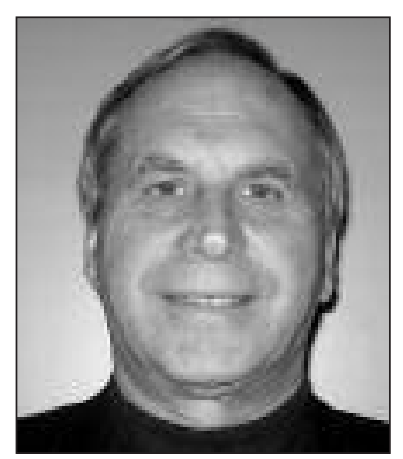

Don Ostaff

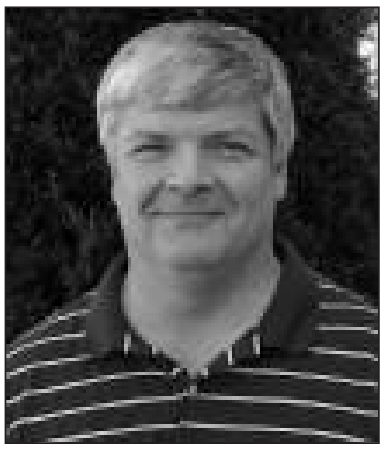

Dan Lavigne coïncide avec les régions où la température moyenne de janvier est inférieure à $-11^{\circ} \mathrm{C}$ et les zones de rusticité des plantes sont supérieures à $4 \mathrm{a}$. La présence de sapin baumier montrant des signes évidents d'attaque par le puceron dans la majeure partie de la Région de l'Atlantique au Canada met en évidence lomniprésence de ce ravageur dans ces provinces et souligne la nécessité de développer des systèmes d'évaluation du risque destiné à la mise en place des programmes de contrôle du ravageur afin de diminuer ses effets.

Mots clés : réchauffement climatique, Adelges piceae Ratz., contrôle des insectes ravageurs forestiers, facteurs abiotiques

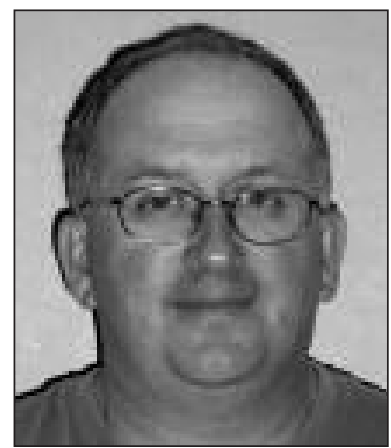

Keith Moore

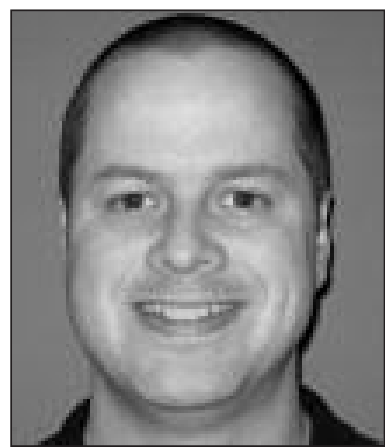

lan DeMerchant

\footnotetext{
${ }^{1}$ Faculty of Forestry and Environmental Management, University of New Brunswick. P.O. Box 44555, Fredericton, New Brunswick E3B 6C2. E-mail: quiring@unb.ca.

${ }^{2}$ Natural Resources Canada, Canadian Forest Service, Atlantic Forestry Centre.

${ }^{3}$ Forest Pest Management Section, Forest Management Branch, N.B. Natural Resources.

${ }^{4}$ Nova Scotia Department of Natural Resources, Integrated Pest Management Group.
} 


\section{Introduction}

Whereas many forest insect pests, such as the eastern hemlock looper, Lambdina fiscellaria fiscellaria (Guen.), spruce bud moth, Zeiraphera canadensis Mutt. and Free., and balsam fir sawfly, Neodiprion abietis (Harris) (Ostaff and Quiring 2000, Hébert et al. 2001, Moreau 2006), usually only occur at high densities in any one area for a relatively short period of time, the balsam woolly adelgid, Adelges piceae Ratz., hereafter referred to as BWA, can remain at relatively high densities for decades (Mitchell and Buffam 2001). Native to Europe, the BWA was first introduced into the Maritime Provinces and New England states approximately 100 years ago (Balch 1932, 1952). It has since colonized Newfoundland, coastal areas of Québec and the west coast of North America (Oregon, Washington and British Columbia) (Martineau 1984). BWA is a pest of true firs (Abies spp.) and is found exclusively on balsam fir (Abies balsamea Mill.) in eastern Canada (Martineau 1984). All BWA are small, female and wingless (Balch 1932). Juveniles, called crawlers, and adults use piercing/sucking mouthparts to feed on host phloem. Balch (1952) reported that a salivary secretion toxic to cells immediately affected by the mouthparts is injected into the phloem during feeding, resulting in a swelling or "gout" condition symptomatic of BWA attack. Its lack of wings limits dispersal and infestations build up locally, causing an irregular or spotty distribution of outbreaks (Balch 1952). The most severely affected trees are unsuitable for lumber owing to uneven shrinkage causing warping and splitting, and pulp is of inferior quality to that from normal wood (Page 1975, Milne 1990). Average volume losses in highly susceptible semi-mature and mature stands can be greater than $80 \%$ (Page 1975). Stem attack can result in growth reductions in excess of 50\%, with high populations killing trees of merchantable size within three years (Balch 1952). Chronic crown infestation can cause a tree to succumb in 10 to 20 years (Carroll and Bryant 1960). Feeding by BWA may also predispose balsam fir trees to Armillaria root rot (Hudak and Singh 1970).

There has been only limited success in reducing damage caused by BWA using insect predators or chemicals (Schooley and Bryant 1978). Damage to balsam fir has been increasingly reported in Atlantic Canada and in Maine during the last 10 years, suggesting that populations of this insect, and the proportion of balsam fir trees damaged by it, may be increasing (Lavigne 2005). With anticipated future wood shortages and increased costs of intensive forest management, it is important to determine the occurrence and significance of BWA damage in balsam fir stands and the influence of abiotic and biotic factors on damage. In an excellent study, Greenbank (1970) showed that survival of overwintering BWA nymphs in several areas of New Brunswick was inversely related to the coldest temperature occurring during the winter and concluded that abiotic conditions limit damage by BWA to balsam fir in colder regions. Similarly, Hartling (2004) and Lavigne (2005) reported that the distribution of damage caused by BWA was related to plant hardiness zones.

As a first step in the development of a hazard rating system for this pest, this report summarizes and extends previous work by examining the association between two estimates of abiotic conditions, winter temperatures and plant hardiness zones, and the distribution of balsam fir trees damaged by BWA in New Brunswick, Newfoundland and Nova Scotia. Plant hardiness zones incorporate the influence of several abiotic variables in addition to temperature (McKenney et al. 2001). Data were collected from provincial forest pest management agencies in Newfoundland, Nova Scotia and New Brunswick, as well as additional data collected by the authors of this study.

\section{Field Surveys to Estimate Damage by BWA}

To determine the distribution of trees displaying symptoms of feeding by BWA, data from 4819 stands was pooled from stands sampled throughout Newfoundland, New Brunswick and Nova Scotia over the period 2004 to 2007. Balsam fir varied from the predominant tree species to only a minor component of the stands. Stands ranged in age from sapling to "overmature" and many contained permanent sample plots used to monitor annual changes in spruce budworm density (Hartling 2004). Balsam fir trees were either examined at road-side, within plots or along a transect within each stand for symptoms of BWA attack, which include gouting, drooping branches and flat-topped crowns (Page 1975). All trees classified as damaged by BWA contained gouting, which is only caused by BWA. Although most visual assessments were used to assign trees to one of four categories (i.e., no, low, moderate or high levels of damage), only the presence or absence of damage is reported here.

\section{Estimates of Winter Temperatures and Plant Hardi- ness Zones}

Preliminary analyses that related mean temperatures from November, December, January and February, obtained from weather stations located throughout New Brunswick, suggested that the distribution of damage by BWA was best explained by January mean temperatures. Consequently, mean monthly temperature rasters were generated using 1971 to 2000 long-term mean monthly temperature layers provided by the CFS-Great Lakes Forestry Centre (http://cfs. nrcan.gc.ca/subsite/glfc-climate) for January for all regions of Newfoundland, New Brunswick and Nova Scotia. When these temperature values were compared to a sample of measured normals from weather stations, they were generally within $0.5^{\circ} \mathrm{C}$ of one another, suggesting that they provide accurate estimates of winter temperatures. The distribution of plots with and without evidence of BWA damage was plotted and contours were generated at $-11^{\circ} \mathrm{C}$ and $-10^{\circ} \mathrm{C}$.

The distribution of plots with and without BWA damage was also overlaid on Canada's plant hardiness zones (McKenney et al. 2001, 2007) available at http://planthardiness. gc.ca/ph_main.pl?lang=en. These plant hardiness zones were based on earlier work by Ouellet and Sherk (1967a, b, c) and take into account various site conditions, such as minimum temperature of the coldest month, mean frost-free period, amount of precipitation, monthly mean of the warmest month, mean maximum snow depth and maximum wind gust speed.

\section{Results}

In New Brunswick, damage by BWA was only observed in the southern and eastern (near the coast) region of the province (Fig. 1). This distribution appears to be strongly influenced by 


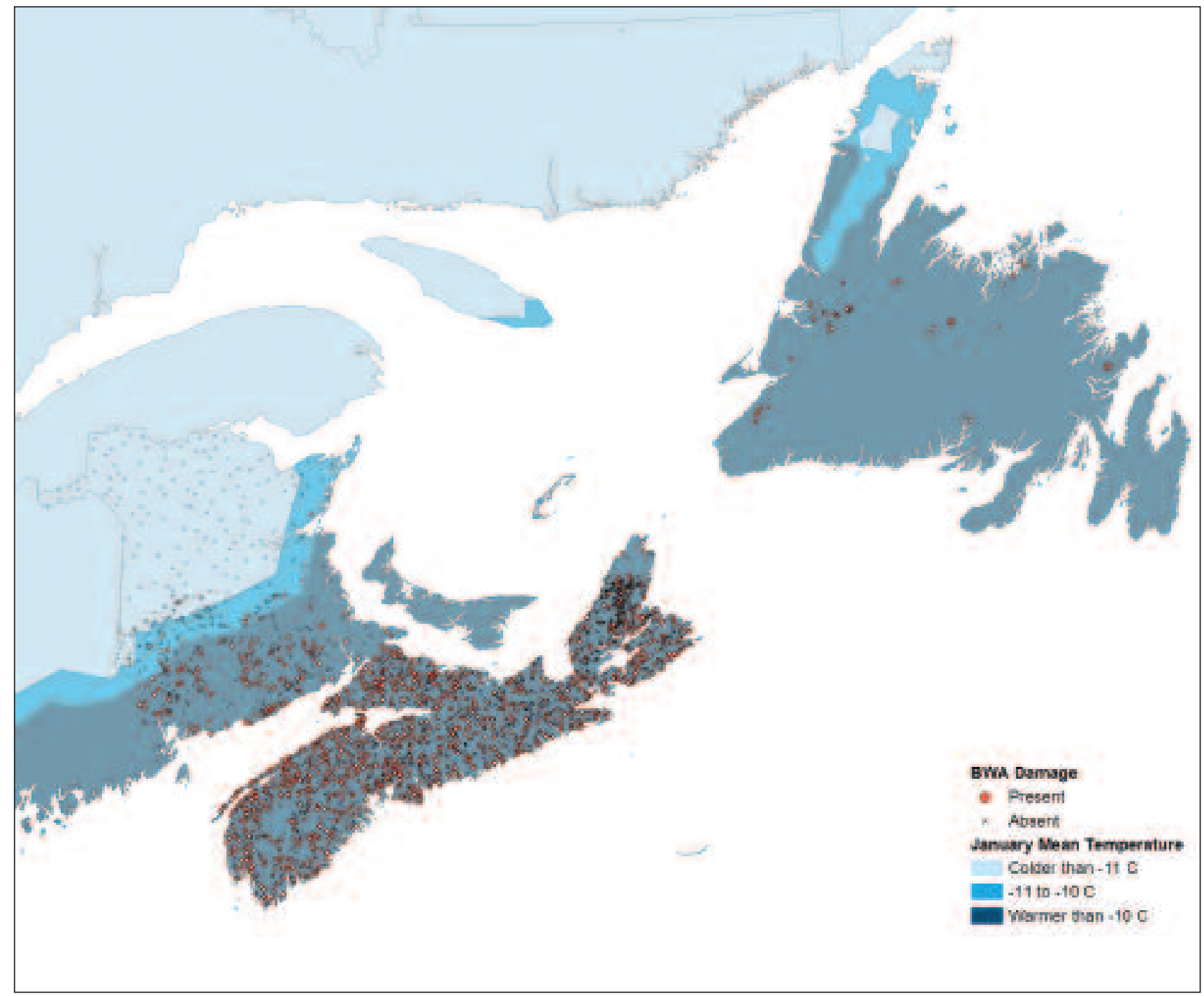

Fig. 1. Relationship between areas in New Brunswick and Newfoundland with mean annual temperatures $<-11^{\circ} \mathrm{C},-10$ to $-11^{\circ} \mathrm{C}$, and $>$ $-10^{\circ} \mathrm{C}$ during January and presence (circles) or absence $(\times s)$ of damage attributable to BWA.

winter temperatures. The presence or absence of damage by BWA was more closely related to mean January temperatures than to mean temperatures for the months of December, February or March. All balsam fir stands containing trees damaged by BWA occurred in areas where the mean annual temperature in January was above $-11^{\circ} \mathrm{C}$ (Fig.1). Many of the stands examined in regions where the mean January temperatures were between -10 and $-11^{\circ} \mathrm{C}$ did not contain trees damaged by BWA, whereas most stands in warmer regions contained BWA-damaged trees. Thus, the $-11^{\circ} \mathrm{C}$ mean January isotherm can explain the presence or absence of BWA damage in all stands surveyed in New Brunswick. All areas of Nova Scotia and all areas of Newfoundland that were surveyed had mean January temperatures above $-11^{\circ} \mathrm{C}$, and most stands surveyed in both provinces showed evidence of BWA damage.

The presence/absence of BWA in New Brunswick was also strongly related to plant hardiness zones. Damage by BWA was absent in all regions with a plant hardiness rating of 4a or lower, but was present in all regions with a plant hardiness rating of $4 \mathrm{~b}$ or higher (Fig. 2). A couple of BWA-damaged stands in western Newfoundland appear to occur in plant hardiness region $4 \mathrm{a}$ (Fig. 2), but this may be a result of the highly variable terrain, with respect to elevation, sun exposure and wind exposure, in the area.

\section{Discussion}

Balsam fir was noticeably damaged by BWA in most stands throughout Nova Scotia, and in southern and eastern New Brunswick. BWA damage was also observed in all stands surveyed in Newfoundland, although fewer stands were sampled than in the other two provinces. This distribution was strongly related to overwintering conditions. All stands that were visibly damaged by BWA were in areas where the mean January temperature was above $-11^{\circ} \mathrm{C}$. This suggests that cold temperatures prevent $\mathrm{BWA}$ populations from attaining densities high enough to produce symptoms of BWA feeding that are visible from the ground. 




Fig. 2. Relationship between plant hardiness zone and presence (circles) or absence $(\times s$ ) of damage by BWA in New Brunswick and Newfoundland.

These results support those of Greenbank (1970), who reported that all BWA died when subjected to $-34^{\circ} \mathrm{C}$ for 24 hours and that $80 \%$ died when exposed to $-30^{\circ} \mathrm{C}$ for five days in lab studies. Similarly, Greenbank (1970) reported that the mortality of BWA in field populations in New Brunswick during winter was inversely and linearly related to the minimum temperature recorded during the winter and that all BWA died when winter temperatures declined below $-35^{\circ} \mathrm{C}$.

The distribution of BWA in Atlantic Canada was also well explained by plant hardiness zones. BWA was found within plant hardiness zone $4 \mathrm{~b}$ and in all warmer zones, but except for one or two sites in Newfoundland, was never found in zones lower than $4 \mathrm{~b}$. The one or two instances where BWA was found in Newfoundland in areas classified as zone $4 \mathrm{a}$ (Fig. 2) probably reflect the large scale of the plant hardiness zone map, which does not take into account all of the large variation in topography in western Newfoundland. It is very possible that all sites examined in western Newfoundland were in plant hardiness zone $4 \mathrm{~b}$. Regardless, the present study suggests that the major factor in the plant hardiness zone classification that explains the distribution of BWA is temperature during the coldest part of winter.

Although no data were shown to support the illustration in Greenbank (1970), the distribution of BWA damage reported 38 years ago is very similar to the distribution reported here. Not surprisingly, the mean January temperature reported by Environment Canada (http://climate.weatheroffice.ec.gc.ca/climateData/canada_e.html) for Fredericton, located just south of the $-11^{\circ} \mathrm{C}$ isotherm, was similar during the period 1960 to 1965 and 2000 to 2005 (i.e., $-9.6 \pm 1.0^{\circ} \mathrm{C}$ versus $-10.8 \pm 1.0^{\circ} \mathrm{C}$ ).

These analyses suggest that warmer winter temperatures would result in a northern movement of BWA in New Brunswick and Newfoundland. Recent studies have predicted that temperatures globally will warm by $0.2^{\circ} \mathrm{C}$ per decade for the next two decades with projections for the rest of the century depending largely on the development path taken, suggesting that the temperature rise by the year 2100 could be as 
low as $1.1^{\circ} \mathrm{C}$ with a shift to a highly renewable energy system or as high as $6.4^{\circ} \mathrm{C}$ with fossil-fuel use remaining much the same as today (http://www.ec.gc.ca/EnviroZine/english/ issues/76/feature2_e.cfm?Issues=October2007). Hayhoe et al. (2006) report that the greatest changes over the last 35 years in northeast United States have been seen in winter, which has warmed at $0.70 \pm 0.05^{\circ} \mathrm{C}$ per decade. An increase in mean January temperatures of $2^{\circ} \mathrm{C}$ would place the $-11^{\circ} \mathrm{C}$ mean isotherm approximately $75 \mathrm{~km}$ farther north in New Brunswick and Newfoundland.

In conclusion, the BWA appears to be widespread throughout Newfoundland and Nova Scotia, and in southern and eastern New Brunswick, and the distribution will move northwards if winter temperatures moderate. The ubiquitous presence of BWA and the large growth loss that it can cause in our most common forest tree, balsam fir, strongly suggest that management of BWA is critical for a productive and sustainable forest industry in Atlantic Canada. We are currently developing hazard ratings for this pest so that forest managers can assess the probability of damage by BWA before making silvicultural decisions, such as planting and thinning. We are also initiating studies to examine genetically based tree resistance to BWA for Christmas tree growers and other field studies to modify pest density-defoliation relationships, used to decide when to apply suppression tactics, for several defoliators on BWA damaged (as opposed to healthy) trees.

\section{Acknowledgements}

We thank Nelson Carter, Hubert Crummey, Mike LeBlanc and Andrew Morrison for their support and insights throughout the course of this study and their helpful comments on an earlier version of this manuscript. We also thank members of the Newfoundland and Labrador Department of Natural Resources, New Brunswick Department of Natural Resources and members of the Nova Scotia Department of Natural Resources, as well as numerous summer students (Laura Buckingham, Leah Flaherty, Renée Fougere, Rob Gray, Bertrand Guillet, Kelvin Hanscomb, Ryan Jennings, Amaury de Maintenant, Lindsey Moore, Don Saunders, Amanda Savoie, Steve Scott and Colleen Teerling) for technical assistance. We gratefully acknowledge Abitibi-Consolidated, Corner Brook Pulp and Paper, Newfoundland and Labrador Department of Natural Resources, Forest Protection Limited, J.D. Irving Ltd., New Brunswick Department of Natural Resources, Nova Scotia Department of Natural Resources, Fundy Model Forest, Southern New Brunswick Woodlot Cooperative and the Spray Efficacy Research Group for access to field sites and/or funding. Funding for publication of this article was provided by Natural Resources Canada, Canadian Forest Service-Atlantic Forestry Centre.

\section{References}

Balch, R.E. 1932. The balsam woolly aphid, Adelges piceae (Ratz.) in Canada. Sci. Agric. 14: 374-383.

Balch, R.E. 1952. Studies on the balsam woolly aphid, Adelges piceae (Ratz.) (Homoptera: Phylloxeridae) and its effects on balsam fir, Abies balsamea (L.) Mill. Can. Dep. Agric. Publ. 867. 76 p.
Carroll, W.J. and D.G. Bryant. 1960. A review of the balsam woolly aphid in Newfoundland. For. Chron. 36: 279-293.

Greenbank, D.O. 1970. Climate and the ecology of the balsam woolly aphid. Can. Entomol. 102: 546-578.

Hartling, L.K. 2004. A qualitative assessment of the distribution of balsam woolly adelgid on balsam fir in New Brunswick, as detected in 2004. Forest Pest Management, New Brunswick Department of Natural Resources, Fredericton, New Brunswick, Canada. 6 p.

Hayhoe, K., C.P. Wake, T.G. Huntington, L. Lifeng, M.D. Schwartz, J. Sheffield, E. Wood, B. Anderson, J. Bradbury, A. DeGaetano, T.J. Troy and D. Wolfe. 2006. Past and future changes in climate and hydrological indicators in the US Northeast. Clim. Dynam. 28: 381-407.

Hébert, C., L. Jobin, R. Berthiaume, C. Coulombe and A. Dupont. 2001. Changes in hemlock looper (Lepidoptera: Geometridae) pupal distribution through a 3-year outbreak cycle. Phytoprotection 82: $57-63$.

Hudak, J. and P. Singh. 1970. Incidence of Armillaria root rot in balsam fir infested by balsam woolly aphid. Canadian Plant Discovery Survey 50: 99-101.

Lavigne, D. 2005. Balsam woolly adelgid work conducted by the NB Brunswick Department of Natural Resources in New Brunswick 2002-2004. Forest Pest Management, New Brunswick Department of Natural Resources, Fredericton, NB.

Martineau, R. 1984. Insects harmful to forest trees. Minister of Supply and Services Canada, Ottawa, Ont. 261p.

McKenney, D.W., M.F. Hutchinson, J.L. Kesteven and L.A. Venier. 2001. Canada's plant hardiness zones revisited using modern climate interpolation techniques. Can. J. Plant Sci. 81: 129-143.

McKenney, D.W., J. Pedlar, K. Lawrence, K. Campbell and M. Hutchinson. 2007. Beyond traditional hardiness zones: using climate envelopes to map plant range limits. BioScience. 57: 929-938.

Milne, G.R. 1990. An economic analysis of the treatment of balsam woolly adelgid in Newfoundland. Forestry Canada, Newfoundland and Labrador Region - Information Report N-X-277. 34.p.

Mitchell, R.G. and P.E. Buffam. 2001. Patterns of long-term balsam woolly adelgid infestations and effects in Oregon and Washington. West. J. Appl. For. 16:121-126.

Moreau, G. 2006. Past and present outbreaks of the balsam fir sawfly in western Newfoundland: an analytical review. For. Ecol. Manage. 221: $215-219$

Ostaff, D.P. and D.T. Quiring. 2000. Population trends of a specialist herbivore, the spruce bud moth, in young white spruce stands. Can. Entomol. 132: 825-842.

Ouellet, C.E. and L.C. Sherk. 1967a. Woody ornamental plant zonation I. Indices of winter hardiness. Can. J. Plant Sci. 47: 231-238. Ouellet, C.E. and L.C. Sherk. 1967b. Woody ornamental plant zonation II. Suitability indices of localities. Can. J. Plant Sci. 47: 339-349.

Ouellet, C.E. and L.C. Sherk. 1967c. Woody ornamental plant zonation III. Suitability map of the probable winter survival of ornamental trees and shrubs. Can. J. Plant Sci. 47: 351-358.

Page, G. 1975. The impact of balsam woolly aphid damage on balsam fir stands in Newfoundland. Can. J. For. Res. 5: 195-209.

Schooley, H.O. and D.G. Bryant. 1978. The balsam woolly adelgid in Newfoundland. Canadian Forest Service, St. John's, Newfoundland. Information Report N-X-160. 